Klin Wochenschr (1991) 69:830-835

Klinische

Wochen

schrift

(C) Springer-Verlag 1991

\title{
Differential Patterns of PMN-Elastase and Type III Procollagen Peptide in Knee Joint Effusions due to Acute and Chronic Sports Injuries
}

\author{
K.-A. Riel ${ }^{1}$, M. Jochum ${ }^{2}$, P. Bernet ${ }^{1}$, and H. Fritz ${ }^{2}$ \\ ${ }^{1}$ Klinik und Poliklinik für Sportverletzungen der Technischen Universität München, Klinikum rechts der Isar; ${ }^{2}$ Abteilung für \\ Klinische Chemie und Klinische Biochemie in der Chirurgischen Klinik Innenstadt, Ludwig-Maximilians-Universität München
}

\begin{abstract}
Summary. In 38 traumatic knee joint effusions the proteolytic enzyme PMN-elastase (PMN-E) and the repair marker procollagen III aminoterminal peptide (PIIINP) were determined. According to the period between trauma and first aspiration of the effusion, the patients were divided into 3 groups. Group I (17 patients; period between trauma and first aspiration not longer than 72 hours) showed high concentrations of PMN-E (up to $5400 \mathrm{ng} / \mathrm{ml}$ ) and low concentrations of PIIINP ( $<13 \mathrm{U} / \mathrm{ml})$. Group II (11 patients; aspiration within 4 to 14 days) had mean PMN-E and PIIINP concentrations of $125.6 \mathrm{ng} / \mathrm{ml}$ and $52.1 \mathrm{U} /$ $\mathrm{ml}$, respectively. In group III (10 patients, aspiration after 14 days) mean PMN-E concentration was $123.8 \mathrm{ng} / \mathrm{ml}$ and mean PIIINP concentration was $63.4 \mathrm{U} / \mathrm{ml}$. Graphic depiction of PMN-E and PIIINP levels in each individual sample as a function of time between trauma and fluid collection revealed highly increasing PMN-E levels during the first 24 posttraumatic hours, followed by rapidly decreasing levels within 72 hours post trauma, and no change after the 4 th posttraumatic day. In contrast, PIIINP increased continuously up to the first posttraumatic week and stayed at high levels up to 90 days (end of the observation period). The differential patterns of PMN-E and PIIINP concentration in knee joint effusions may be useful in estimating the period between trauma and first treatment (aspiration of effusion) and should, therefore, be helpful in detecting degenerative lesions, which seem to be characterized by low PMN-E concomitantly with high PIIINP levels.
\end{abstract}

Key words: Traumatic knee joint effusion - PMNelastase - Type III procollagen peptide

Abbreviations: PMN-E=elastase from polymorphonuclear granulocytes; PIIINP = procollagen III aminoterminal peptide; $\alpha 1 \mathrm{PI}=\alpha 1$-proteinase inhibitor
The extracellularly released lysosomal serine proteinase elastase (PMN-E) from polymorphonuclear (PMN) granulocytes plays an important role as a nonspecific mediator of local inflammation by degrading a variety of matrix proteins in situ until being inhibited by its main antagonist $\alpha_{1}$-proteinase inhibitor $[14,19]$. Large amounts of elastase $(9947 \pm 124 \mathrm{mg} / 1)$ were measured in complex with $\alpha_{1}$-proteinase inhibitor in close relation to the number of granulocytes in the inflammatory synovial fluid of patients suffering from arthritis [16]. Moreover, following knee injury the activity of lysosomal enzymes in synovial fluids increased with the extent of trauma [9]. In contrast to destructive processes involved in the inflammatory response, repair and healing is characterized by the proliferative phase of the synovial tissue. Augmented synthesis of collagen is thus detectable by increasing levels of porcollagen peptides, for example of type III aminoterminal procollagen peptide (PIIINP), in the joint fluid [10]. The N-terminal propeptide (Col 1-3, Mr 45000 ) is cleaved off in a stoichiometric manner during the conversion of procollagen to collagen and is, therefore, considered as a marker of tissue remodeling $[11,21,22$, 26].

The goal of this prospective study was to find out whether acute and chronic traumatic knee joint effusions induced by sports injuries can be characterized by PMN-E and PIIINP concentrations in relation to the onset of trauma.

\section{Patients and Methods}

In the period of January to March 1990 , knee joint effusions of 38 patients suffering from sports injuries were aspirated. The mean age of the patients was 30 years, ranging from 14 to 59 years. With regard to trauma history, these 38 patients could 
be divided into three groups (Table 1). Group 1 consisted of 17 patients with acute fresh lesions, in whom aspiration was performed within 72 hours. In the 11 patients of group II, aspiration was performed within 4 to 14 days, and for the 10 patients of group III, the period between trauma and aspiration was longer than 14 days. All patients underwent arthroscopy and/or arthrotomy for ligament and/or meniscal repair (Table 2).

The samples were anticoagulated $(1 \mathrm{ml}$ citrate to $9 \mathrm{ml}$ effusion), and centrifuged at $1500 \mathrm{~g}$ for ten minutes. Aliquots of the cell-free supernatant were immediately frozen and stored at $-70^{\circ} \mathrm{C}$ for up to 6 months until assayed.

PMN-E in synovial fluids in complex with $\alpha 1$ proteinase inhibitor ( $\alpha 1 \mathrm{PI})$ was determined according to Neumann [20] using a specific two-site sandwich ELISA (Merck, Darmstadt, Germany). Moreover, to detect proteolytically active elastase which may not be inhibited in the local inflammatory environment due to lack of sufficient inhibitory active $\alpha 1 \mathrm{PI}$, one part of each synovial fluid was mixed with a surplus of purified $\alpha 1 \mathrm{PI}$ and reassayed for an in vitro increase of the elastase- $\alpha 1 \mathrm{PI}$ complex.

PIIINP was determined by a new version (RIAgnost Procollagen III Peptide; Behringwerke, Marburg, Germany, Prod. No. OCFK) of the radioimmunoassy originally described by Rohde [23]. The new test system (IRMA) uses the principle of a 2-stage sandwich assay. A complex of solid-phase bound monoclonal antibodies against PIIINP (Col 1-3), PIIINP in the sample, and ${ }^{125}$ I-labelled monoclonal anti-PIIINP antibodies is formed during the assay procedure. At the end of reaction (incubation times were reduced by us to $3 \mathrm{~h}$ ) the free tracer is removed and the amount of tracer specifically bound to the coated tubes is measued with a gamma scintillation counter. The monoclonal antibodies used in the kit are highly specific for the peptide Col 1-3. The possibility of a crossreaction with other basal membrane proteins that are physiologically relevant can be virtually ruled out. Cross-reactivity with proteolytic degradation products $(\mathrm{Col} 1, \mathrm{Mr} 10000)$ is about $10 \%$ (product information, Behringwerke). $1 \mathrm{U} / \mathrm{ml}$ measured with the new test version corresponds to about $15 \mathrm{ng} / \mathrm{ml}$ quantified with the original procedure (own data obtained from 50 serum samples measured with both assay versions).

Since the test kit is constructed primarily to quantify PIIINP in plasma or serum samples, we first checked the reliability of the assay to measure PIIINP adequately in snyovial fluids. For this,
Table 1. Demographic data of 38 patients with traumatic knee joint effusions. With regard to the period between trauma and first aspiration, patients were divided into three groups. Dataare given as mean and range

\begin{tabular}{llll} 
& Group I & Group II & Group III \\
\hline Patients & $n=17$ & $n=11$ & $n=10$ \\
Female/male & $3 / 14$ & $6 / 5$ & $1 / 9$ \\
Mean age & $24 \pm 4$ & $28 \pm 7$ & $36 \pm 13$ \\
(years) & $(14-36)$ & $(20-43)$ & $(18-59)$ \\
$\begin{array}{l}\text { Days after } \\
\text { trauma }\end{array}$ & 1.7 & 8 & 29 \\
\hline
\end{tabular}

Table 2. Knee joint effusions and the arthroscopically confirmed lesions of 38 patients with sports injuries (see also Table 1). In group II and group III, i.e., the older lesions, concomitant cartilage damages increased

\begin{tabular}{|c|c|c|c|}
\hline & Group I & Group II & Group III \\
\hline Hemarthrosis & 17 & 5 & 2 \\
\hline Serous effusion & - & 6 & 8 \\
\hline $\begin{array}{l}\text { Rupture of anterior } \\
\text { cruciate ligament }\end{array}$ & 12 & 1 & 2 \\
\hline $\begin{array}{l}\text { Rupture of } \\
\text { collateral ligament }\end{array}$ & 9 & 2 & - \\
\hline Tear of meniscus & 7 & 7 & 11 \\
\hline Flake fracture & 7 & 2 & 2 \\
\hline Damage of cartilage & - & 6 & 10 \\
\hline
\end{tabular}

samples of synovial fluid with a low PIIINP amount $(<2 \mathrm{U} / \mathrm{ml})$ were spiked with 5 or $10 \mathrm{U} / \mathrm{ml}$ of the PIIINP standard. The recovery was 86 and $92 \%$, respectively. In addition, a sample of synovial fluid containing about $10 \mathrm{U}$ PIIINP/ml (quantified by using the normal standard curve for serum samples) was diluted according to the standards of the kit. Both the standards and the synovial fluid dilutions gave similar slopes. In citrated plasma samples, the intraassay variations for mean values of $2.1,8.8$, and $17.4 \mathrm{U} / \mathrm{ml}$ were $2.4,3.1$ and $1.9 \%$, respectively; the interassay variation for mean value of $1.8 \mathrm{U} / \mathrm{ml}$ was $5.6 \%$.

Data are expressed as mean \pm standard deviation and range. Using the Kruskal-Wallis test $\mathrm{P}$ values $\leq 0.05$ were considered significant.

\section{Results}

In group I, all patients ( $n=17)$ had a hemarthrosis of $42 \pm 27(12-110) \mathrm{ml}$. Severe combined knee joint lesions were detected by arthroscopy. In 12 cases acute anterior cruciate ligament ruptures were 
Table 3. Mean and standard deviation of PMN-E and PIIINP concentrations in knee joint effusions of 38 patients with sports injuries (see also Table 1) and of the aspirated volume. Group I showed significantly (*) different values of PMN-E and PIIINP compared with group II or group III

\begin{tabular}{lcccc}
\hline & Group I & Group II & Group III & $p$-value \\
\hline PMN-E ng/ml & 2251 & 125.6 & 123.8 & $<0.005$ \\
& $\pm 1647^{*}$ & \pm 38.4 & \pm 66.1 & \\
PIIINP U/ml & 5.7 & 52.1 & 63.4 & $<0.005$ \\
& $\pm 3.3^{*}$ & \pm 38.4 & \pm 28.7 & \\
Volume ml & 42 & 32 & 32 & $>0.05$ \\
& \pm 27 & \pm 26 & \pm 12 & \\
\hline
\end{tabular}

found. Biochemical analysis revealed elastase- $\alpha 1 \mathrm{PI}$ concentrations of $2251 \pm 1647(121-5439) \mathrm{ng} / \mathrm{ml}$ and PIIINP levels of $5.7 \pm 3.3(1.8-12.3) \mathrm{U} / \mathrm{ml}$ (Table 3 ). Yet, no proteolytically active elastase was measurable in these synovial fluid samples.

In group II $(n=11), 6$ synovial effusions, 4 sanguinary effusions, and one pure hemarthrosis were aspirated. The volume was $32 \pm 26(10-90) \mathrm{ml}$. Meniscus tear was the most frequently found knee joint lesion, only very seldom combined with ligament ruptures. In 6 cases concomitant cartilage damages were seen. Elastase- $\alpha 1 \mathrm{PI}$ concentrations of 125.6 $+38.4(83-202) \mathrm{ng} / \mathrm{ml}$ and PIIINP concentrations of $52.1 \pm 38.4(13-120) \mathrm{U} / \mathrm{ml}$ were quantified in this group of patients (Table 3 ).
In the 10 patients of group III, 8 synovial effusions of $32 \pm 12(15-65) \mathrm{ml}$ were aspirated, and the mostly revealed lesions were meniscus tears. In all these 10 patients advanced cartilage damages were found (Table 2). The level of complexed elastase was $123.8 \pm 66.1(60-331) \mathrm{ng} / \mathrm{ml}$ and that of PIIINP was $63.4 \pm 28.7$ (31-133) $\mathrm{U} / \mathrm{ml}$ (Table 3 ).

Thus, traumatic knee joint effusions contain high concentrations of PMN-E (up to $5400 \mathrm{ng} / \mathrm{ml}$ ) and low concentrations $(<13 \mathrm{U} / \mathrm{ml})$ of PIIINP in the case of acute injuries. In contrast, a low concentration of PMN-E (up to $330 \mathrm{ng} / \mathrm{ml}$ ) and a high concentration (up to $133 \mathrm{U} / \mathrm{ml}$ ) of PIIINP were measured in chronic injuries.

Although no serial synovial fluid samples could be taken from our patients, the graphic depiction of PMN-E and PIIINP values in each individual sample as a function of time between trauma and sample collection shows the following characterization of the posttraumatic period (Fig. 1): PMNE levels increased to a maximum within the first 24 hours, then decreased rapidly during the next 48 hours and stayed at a relatively low range after the 4 th posttraumatic day. In contrast, PIIINP levels continuously increased up to the first posttraumatic week, and no significant decrease was measured during the further observation period of nearly 90 days. Statistical calculation (KruskalWallis test) revealed (Table 3 ) that concentrations of elastase in group I were significantly higher than

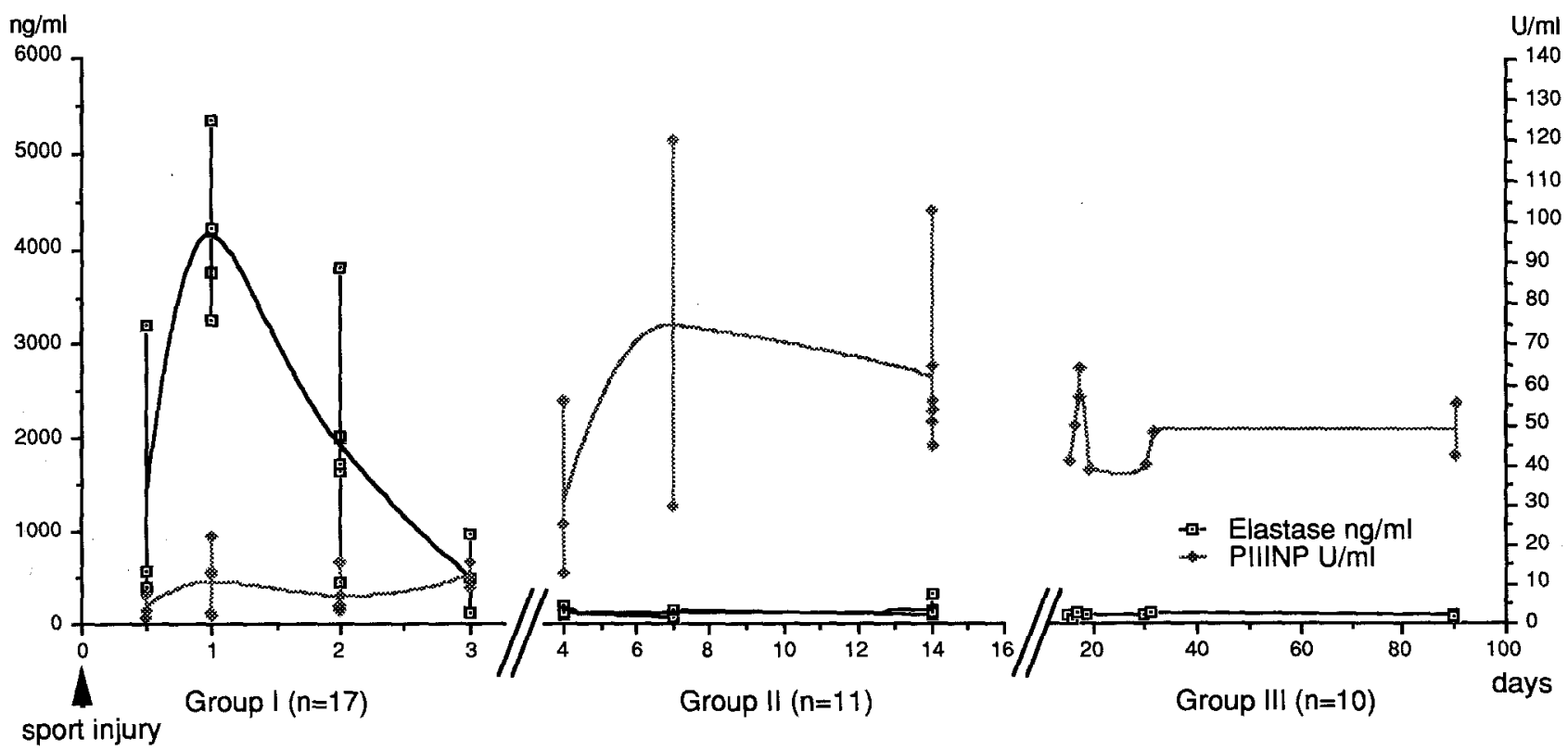

Fig. 1. Concentrations (vertical bars $=$ range) of PMN-elastase (in complex with $\alpha 1$-proteinase inhibitor; $\mathrm{n} / \mathrm{ml}$ ) and procollagen III peptide $(\mathrm{U} / \mathrm{ml})$ in traumatic knee joint effusions $(n=38)$ related to the period between trauma and first aspiration. Traumatic knee joint effusions are characterized by high levels of elastase immediately after trauma (group I) and by increasing PIIINP and highly elevated concentrations, respectively, in the following period (groups II and III) 
those in group II or III $(p \leq 0.005)$, but there was no difference between groups II and III $(p \leq 0.4)$. Similarly, a significant difference between concentrations of PIIINP in group I compared to group II or IIII $(p \leq 0.005)$ could be evaluated, but no difference between groups II and III with regard to PIIINP concentrations. Age, sex, or aspirated volume had no influence ( $p \geq 0.05)$.

\section{Discussion}

After trauma, the presence of a hemarthrosis is a sign of severe joint lesion. Hemarthrosis leads to synovial hypertrophy and siderosis, which indicates the synovial cells are capable phagocytosis of erythrocytes and hemoglobin. In order to form siderosomes, the phagocytic cells have to synthesize lysosomes containing destructive enzymes [5]. In contrast, phagocytic PMN granulocytes and monocytes attracted to the inflammatory focus contain already preformed lysosomes with active proteinases (e.g., elastases and cysteine proteinases). Therefore, an increase in extracellularly released lysosomal enzyme activity may be expected in traumatic knee joint effusions, since during the phagocytic process these enzymes are also discharged from the cells.

In synovial fluids of patients with rheumatoid arthritis, three different fractions of elastase-type enzymes were found: (1) a serine type (originating from PMN granulocytes or monocytes), (2) a metallo type (from monocytes/macrophages), and (3) a fraction (of unknown origin) which was resistant to both serine enzyme and metallo enzyme inhibitors [6]. Inflammatory synovial fluids of rheuma patients are characterized by constantly very high elastase levels (mean: $9947 \pm 124 \mathrm{ng} / \mathrm{ml}$ ) compared with elastase levels of $41 \pm 0.5 \mathrm{ng} / \mathrm{ml}$ in non-inflammatory synovial fluids [16]. From in vitro and in vivo studies it is known that the lysosomal serine enzyme elastase of PMN granulocyte is able to cleave a large number of substrates, for example matrix proteins [19] or IgG in rheumatic fluids [4]. In vivo extracellularly discharged PMN-E is rapidly complexed by the plasma inhibitors $\alpha_{1}$-proteinase inhibitor $(90 \%)$ and $\alpha_{2}$-macroglobulin $(10 \%)$. Therefore, in biological fluids, especially in plasma, elastase is measured primarily as the inactive enzyme in complex with $\alpha_{1}$-proteinase inhibitor $[12,20]$. Yet, in inflammatory local body fluids the inhibitory potential may be consumed to such a degree that proteolytically active elastase is also present $[1,13]$.

In our 38 joint effusions induced by sports injuries, the extracellularly released lysosomal serine proteinase elastase from PMN granulocytes in complex with $\alpha_{1}$-proteinase inhibitor showed high levels (up to a mean of $2280 \mathrm{ng} / \mathrm{ml}$ ) during the first 48 hours after the traumatic event, whereas after a longer interval (more than 4 days) between injury and effusion sampling, clearly elevated elastase levels could be no longer detected. This is in accordance with results of another study, where concentration of complexed elastase, leukocyte count, and the activity of several other lysosomal enzymes were found to increase with the severity of joint lesions reaching maximum mean values (PMN-E: $3940 \pm 1009 \mathrm{ng} / \mathrm{ml}$ ) two to three days after trauma, followed by a significant decrease over the next few days [9]. In a further study cartilage damages, tears of meniscus or ligament ruptures due to injuries were associated with a dramatic release of proetoglycan fragments to the synovial fluids during the acute posttraumatic phase. These elevated levels of fragments gradually decreased over time $[17,18]$. Interestingly, a similar behavior was shown in our study for the extracellularly released elastase, which is known as one of the most potent lysosomal enzymes inducing the breakdown of proteoglycans. Although no proteolytically active elastase was measurable in any of our synovial fluid samples, one can assume that at least for a very short time high amounts of discharged elastase may be able to degrade humoral and structural proteins until the enzyme activity is eventually blocked by $\alpha 1$ PI $[2,25]$.

During the inflammatory proliferative phase, synovial tissue is also characterized by stimulated syntheis and deposition of types I and III collagen as an indication of repair processes [7]. The increased synthesis of collagen is accompanied by detectable levels of collagen in the joint fluid, the amount of collagen being roughly proportional to the degree of cartilage loss as assessed radiologically [3]. During the conversion of procollagen to collagen, the type III aminoterminal procollagen peptide (PIIINP) is cleaved off in a stoichiometric manner [26]. Therefore, PIIINP may be considered as a marker of tissue remodeling and repair [10]. Measurement of PIIINP in serum has been suggested as a useful tool in the diagnosis and followup of various fibrotic conditions, particularly of liver diseases [24]. Yet, increased serum levels of PIIINP and its degradation products were found also in patients with theumatoid arthritis $[8,10$, 11, 12]. Patients with active disease showed higher serum PIIINP levels than patients with inactive disease or healthy individuals. Therefore, the PIIINP serum level seems to reflect disease activity in rheumatoid arthritis and was suggested to be 
a valuable prognostic marker in such disorder [10] In contrast, PIIINP concentrations in synovial fluids from patients with inflammatory (e.g., rheumatoid arthritis, septic arthritis) and non-inflammatory (e.g., arthrosis, traumatic lesions) joint diseases did not reveal signifiant differences. Mean values were shown to be more than 1,000 times higher than in serum under both pathological conditions [8]. In 41 synovial fluid samples of noninflammatory joint diseases due to traumatic lesions or arthrosis, these values varied between approximately $190 \mathrm{ng} / \mathrm{ml}$ and $2,900 \mathrm{ng} / \mathrm{ml}$, with a mean of $1,390 \mathrm{ng} / \mathrm{ml}$. Taking into account that $15 \mathrm{ng} / \mathrm{ml}$ quantified by the authors [8] using the original test version from Behringwerke corresponds to $1 \mathrm{U} / \mathrm{ml}$ measured with our test system, the range of PIIINP levels would have been between 13 to $194 \mathrm{U} / \mathrm{ml}$. This is in accordance with the results obtained in group II and III patients (sample collection from the 4th to the 90th posttraumatic day) of our study (PIIINP range: 13 to $133 \mathrm{U} / \mathrm{ml}$ ). In contrast, PIIINP levels in synovial fluids of our group I patients (sample collection within $72 \mathrm{~h}$ post trauma) ranged only from 1.8 to $12.3 \mathrm{U} / \mathrm{ml}$ with a mean of $5.7 \mathrm{U} / \mathrm{ml}$ probably indicating "normal" PIIINP levels in this early posttraumatic phase. Although "normal" synovial fluid was not available to us, this assumption is based on the only slightly varying PIIINP values throughout this time and on results published by Horselev-Petersen et al. [10] who measured $162 \mathrm{ng}$ / $\mathrm{ml}$ (corresponding to about $11 \mathrm{U} / \mathrm{ml}$ ) in a synovial fluid sample obtained from a healthy woman, whereas patients with reactive arthritis showed highly elevated synovial fluid PIIINP levels (497$2,441 \mathrm{ng} / \mathrm{ml}$ comparable to $33-142 \mathrm{U} / \mathrm{ml})$. Yet, another cause for the low PIIINP levels in the first three posttraumatic days should be also taken into account. Since highly elevated extracellularly released PMN-E could be measured especially in samples taken two or three days after trauma, proteolytic degradation of the PIIINP molecules cannot be ruled out completely, indicating that the split products had not been recognized by our test system highly specific for the intact Col 1-3 molecule. Due to experimental limitations in our laboratory such split products cannot as yet be identified by other methods. However, two facts contradict the supposition of proteolytic degradation of the PIIINP molecules in vivo by elastase. First, there is no quantitative correlation $(=0.055, r$ squared $=0.003$ ) between the corresponding elastase and PIIINP levels in the synovial fluids taken during the early posttraumatic phase (Fig. 1). Second, highly elevated PIIINP levels have been mea- sured by several authors $[8,10,11,12]$ in synovial fluids of patients suffering from inflammatory rheuamtic disorders, despite the fact that other authors have also proven extremely elevated extracellular elastase levels in snyovial fluids of patients with such diseases $[15,16]$.

Therefore, the results of our pilot study can be summarized as follows: PMN-E as a nonspecific mediator of local inflammation and PIIINP as a presumable marker of repair or fibrosis, respectively, have been determined in 38 traumatic knee joint effusions induced by acute or chronic sports injuries. The results show that traumatic knee joint effusions contain

1. high concentrations of PMN-E (up to $5,400 \mathrm{ng} /$ $\mathrm{ml})$ and low concentrations $(<13 \mathrm{U} / \mathrm{ml})$ of PIIINP in case of acute injury (group I patients)

2. low concentrations of PMN-E (up to $330 \mathrm{ng} / \mathrm{ml}$ ) and high concentrations (up to $133 \mathrm{U} / \mathrm{ml}$ ) of PIIINP in case of chronic injury (group II and III patients).

The results also demonstrate that the posttraumatic period is characterized by

1. PMN-E: high increasing levels during the first 24 hours, rapidly decreasing levels within 48 hours, no change after the 4th posttraumatic day

2. PIIINP: continuously increasing levels from the 4th posttraumatic day up to the first posttraumatic week; highly elevated levels in case of degenerative lesions.

Due to the differential patterns of PMN-E and PIIINP concentrations in knee joint effusions, the measurement of both parameters together may be useful in estimating the period between trauma and first treatment (aspiration of effusion). In this way it should be possible to detect degenerative lesions, which seem to be characterized by low levels of PMN-E and high levels of PIIINP. To confirm these conclusions, we are currently performing a more extended study, investigating also serial synovial samples from individual patients.

\section{References}

1. Billing A, Fröhlich D, Jochum M, Kortmann H (1988) Impaired phagocytosis in peritonitis exudate secondary to complement consumption. Surg Res Comm 3:335-345

2. Campbell EJ, Senior RM, McDonald AJ, Cox DL (1982) Proteolysis by neutrophils. Relative importance of cell-substrate contact and oxidative inactivation of proteinase inhibitors in vitro. J Clin Invest 70:845-852

3. Cheung HS, Rayan LM, Kozin F, McCarty DJ (1980) Identification of collgen subtypes in snyovial fluid sediment from arthritic patients. Am J Med 68:73-79 
4. Eckle I, Kolb G, Neurath F, Havemann K (1988) Detection of granulocyte elastase specific IgG split products in rheumatoid synovial fluid. Adv Exp Med Bio 240:531-534

5. Faby $G$ (1989) Ultrastructural changes in synovium and cartilage in experimental hemarthrosis in dogs. Arch Orthop Trauma Surg 109:21-29

6. Frank C, Byrjalsen I (1990) Fractionation of elastase-type enzyme activity in biological fluids using a centrifugal analyser. Biol Chem Hoppe Seyler 371:465-469

7. Gay S, Gay RE, Miller EJ (1980) The collagens of the joint. Arthritis Rheum 23:937-942

8. Gressner AM, Neu H-H (1984) N-terminal procollagen peptide and $\beta 2$ microglobulin in synovial fluids from inflammatory and non-inflammatory joint diseases. Clin Chem Acta $141: 241-245$

9. Hörl M, Bruch H-P (1988) Lysosomal enzymes and granulocyte elastase in synovial fluid after multiple traumatic injuries. Adv Exp Med Biol 240:519-522

10. Horslev-Petersen K, Bentsen KD, Junker P, Lorenzen I (1986) Serum amino-terminal type III procollagen peptide in rheumatoid arthritis. Relationship to disease activity, treatment, and development of joint erosions. Arthritis Rheum 29:592-599

11. Horslev-Petersen K, Saxne T, Haar D, Thomsen BS, Bentsen KD, Junker P, Lorenzen I (1988) The aminoterminaltype-III procollagen peptide and proteoglycans in serum and synovial fluid of patients with rheumatoid arthritis or reactive arthritis. Rheumatol Int $8: 1-9$

12. Horslev-Petersen K, Bentsen KD, Junker P, Mathiesen FK, Hansen TM, Lorenzen I (1988) Serum aminoterminal typeIII procollagen peptide in inflammatory and degenerative rheumatic disorders. Clin Rheumatol 7:61-68

13. Jochum M (1991) Specific proteins of inflammatory cells and $\alpha 1$-proteinase inhibitor in alveolar epithelial lining fluid of polytrauamtized patients. Do they indicate posttraumatic lung failure? In: Sturm JA (ed) Adult respiratory distress syndrome. Springer, Berlin Heidelberg New York, pp 193211

14. Jochum M, Fritz H, Nast-Kolb D, Inthorn D (1990) GranuIocyten-Elastase als prognostischer Parameter. Komplikationen bei Indensivpflege-Patienten. Dtsch Aerztebl $87: 1106-1110$

15. Kuramitsu K, Yoshida A (1990) Plasma and synovial fluid levels of granulocytal elastaase- $\alpha$-1-protease inhibitor complex in patients with rheumatoid arthritis. Rheumatol Int $10: 51-56$
16. Kleesik K, Greiling H (1984) Pathobiochemical mechanisms during the acute phase response. Int $J$ Microcirc Clin Exp $3: 131-137$

17. Lohmander LS, Dahlber L, Ryd L, Heinegard D (1989) Increased levels of proteoglycan fragments in knee joint fluid after injury. Arthritis Rheum 32:1434-1441

18. von der Mark K, Glückert K (1990) Biochemische und molekularbiologische Aspekte zur Früherfassung humaner Arthrosen. Orthopäde 19:2-15

19. McGowan SE, Murray JJ (1987) Direct effects of neutrophil oxidants on elastase-induced extracellular matrix proteolysis. Am Rev Respir Dis 135:1286-1293

20. Neumann S, Gunzer G, Hennrich N, Lang H (1984) "PMN-Elastase Assay" enzyme immunoassay for human polymorphonuclear elastase complexed with $\mathrm{a}_{\mathbf{1}}$-proteinase inhibitor. J Clin Chem Clin Biochem 22:693-697

21. Nimi ME (1983) Collagen structure, function, and metabolism in normal and fibrotic tissue. Semin Arthritis Rheum $13: 1-86$

22. Prockop DJ, Kivirikko KI, Tuderman L, Guzman NA (1979) The biosynthesis of collagen and its disorders. $\mathrm{N}$ Engl J Med 301:13-23

23. Rohde $H$, Vargas $L$, Hahn $E$, Kalbfleisch $H$, Bruguera $M$, Timpl R (1979) Radioimmunoassay for type III procollagen peptide and its application to human liver disease. Eur J Clin Invest 9:451-459

24. Rojkind M (1984) The blue glass and the predictive value of serum aminoterminal propeptide of type III procollagen as a marker of liver fibrosis. Hepatology 4:977-978

25. Sandhaus RA (1987) Elastase may play a central role in neutrophil migration through connective tissue. In: Taylor JC, Mittmann Ch (eds) Pulmonary emphysema and proteolysis. Academic Press, Orlando, pp 227-233

26. Timple R, Glanville RW (1981) The aminopropeptide of collagen. Clin Orthop 158:224-242

Received: February 25, 1991

Returned for revision: April 29, 1991

Accepted: July 22, 1991

Dr. K.-A. Riel

Klinik und Poliklinik für Sportverletzungen TUM

Connollystrasse 32

W-8000 München 40, FRG 